\title{
Vi blir tilfreds til slutt
}

«Skandalene i helsetjenesten synes uten ende,» skrev legene Jannicke Mellin-Olsen, Kjetil Karlsen og Sven Erik Gisvold i en kronikk like før jul (1). Det har vi hørt før. Det nye var at de tre la frem forslag til hva helseministeren burde gjøre. Det føltes befriende. Vi er vant til beskrivelser av helsevesenets elendige tilstand, men sjelden får vi forslag om hva som kan gjøres. Riktignok var trepunktsplanen lite utviklet, men den ble lagt merke til (2). Hvis Jonas Gahr Støre makter å snu den rådende styringsideologien, kan han bli statsmannen som berger et godt og velfungerende offentlig helsevesen i Norge, skrev de (1). «Vi venter i spenning,» kommenterte Klassekampens redaktør (2). Det tror jeg det er liten grunn til.

Etter alt å dømme kommer helsevesenet - i stort - til å utvikle seg langs de samme linjer som har vært herskende i mange år nå. En rekke faktorer bidrar til det, ikke minst behovet for å begrense veksten i helseutgiftene. Ingen helseminister vil kunne endre på det. Snarere tvert imot. De neste årene vil helsepolitikken mest sannsynlig bli strammere enn det vi har sett hittil. Prioritering av helsetjenester, både hvilke, hvor og til hvem, vil uvilkårlig presse seg mer frem. Hva vil dette innebære for oss leger? Et eksempel fra klassisk sosialpsykologi kan gi oss et svar $(3,4)$.

Det er velkjent at vi mennesker har stort behov for å være konsistente. Derfor vil vår atferd og våre holdninger som regel være i samsvar. Vi vil helst leve som vi lærer. Det må være en viss orden og sammenheng i oss selv og omverdenen (5). Men unntak finnes. Alle vet at røyking er usunt. Likevel er det mange som fortsetter med det. Røykerne vil derfor oppleve en inkonsistens mellom atferd og holdninger. Denne konflikten mellom handling («jeg røyker») og kunnskap («det er helseskadelig å røyke») tåler vi dårlig. Derfor vil de som røyker forsøke å rettferdiggjøre sin atferd, for eksempel ved å bagatellisere den: «Det er ikke så farlig å røyke som legene sier» $(5,6)$. Den amerikanske sosialpsykologen Leon Festinger (1919-89) beskrev dette fenomenet i slutten av 1950årene og kalte det «kognitiv dissonans» - det er konflikt mellom det vi tenker og det vi gjør $(3,4)$. Festinger mente at slik dissonans skaper et psykologisk ubehag som vil motivere oss til endring for å oppnå konsistens. Her er parallellen til helsevesenet: Legene opplever mangel på samsvar mellom det de mener er riktig å gjøre og hvilke rammer de har. Mange forteller for eksempel at de gir beskjed oppover i systemet, men ikke blir hørt. Dette er en tilstand av kognitiv dissonans - det vi gjør, stemmer ikke overens med det vi mener. Slikt ubehag kan vi ikke tåle over tid.
Det finnes ulike måter å redusere den kognitive dissonansen på én er ved å endre holdninger. Kognitiv dissonans kan altså bidra til holdningsendring (7). Og her trer mitt bilde av det nye norske helsevesen frem: Leger og andre helsearbeidere vil gradvis endre seg, slik at det vi tidligere mente var riktig utøvelse av yrket, hva som motiverte oss, hva vi oppfattet som viktigst, vil være annerledes. Vi vil tilpasse oss systemet og ikke bare akseptere tingenes tilstand, men også mene at det må være og er best slik. Teorien om kognitiv dissonans lærer oss altså at det for helsebyråkrater, administratorer og politikere gjelder å holde ut. Hvis de gjør det, kan nemlig det vidunderlige skje: De som arbeider i helsevesenet, vil tilpasse seg den den rådende styringsideologien. Vi vil mene at bunnlinjen er viktigst, at det er mange fordeler med å være produksjonsarbeidere i helsefabrikker og at effektivitet er det mest sentrale i lege-pasient-forholdet.

Et usannsynlig dystopisk skrekkscenario? Selvsagt har jeg trukket både modell og tolking langt $(8,9)$. Men la meg være litt personlig. Nylig gjennomgikk jeg en personlighetstest på jobben. Et firma skulle kartlegge personlighetsprofilene våre. På én av variablene skåret jeg fullt hus. Jeg var $100 \%$ «tilpasningsdyktig». Tolkingen av et slikt uvanlig resultat, forklarte konsulenten, var at jeg med letthet kan tilpasse meg enhver arbeidsplass. Jeg kan finne meg til rette alle steder. Det var da jeg forsto hvordan det hang sammen. Jeg vil være den ideelle arbeider i Det Nye Norske Helsevesen.

\section{Litteratur}

1. Mellin-Olsen J, Karlsen K, Gisvold SE. Hva Støre bør gjøre. Dagbladet 10.12.2012: 48-9. www.dagbladet.no/2012/12/10/kultur/debatt/kronikk/helse/ sykehus/24759706 (2.1.2013).

2. Braanen B. Helsepolitikk. Klassekampen 11.12.2012: 2. www.klassekampen.no/ 60966/article/item/null/helsepolitikk (2.1.2013).

3. Aronson E. Back to the future: retrospective review of Leon Festinger's «A Theory of Cognitive Dissonance». Am J Psychol 1997; 110: 127-37.

4. Draycott S, Dabbs A. Cognitive dissonance. 1: An overview of the literature and its integration into theory and practice in clinical psychology. Br J Clin Psychol 1998; $37: 341-53$

5. Kognitiv dissonans (15.11.2012). I: Store norske leksikon. http://snl.no/ kognitiv_dissonans (2.1.2013)

6. Kneer J, Glock S, Rieger D. Fast and not furious? Reduction of cognitive dissonance in smokers. Soc Psychol 2012; 43: 81-91.

7. Harmon-Jones E, Amodio DM, Harmon-Jones C. Action-based model of dissonance: a review, integration, and expansion of conceptions of cognitive conflict. Adv Exp Soc Psychol 2009; 41: 119-65.

8. Svartdal F, red. Psykologi: en introduksjon. 2. utg. Oslo: Gyldendal Akademisk, 2011: $206-7$.

9. Passer M, Smith R, Holt N et al. Psychology: the science of mind and behaviour. London: McGraw-Hill, 2009: 610-1. 